\title{
Occurrence of Stunt Nematode, Tylenchorhynchus claytoni, on Turfgrass in Korea
}

\author{
Zakaullah Khan ${ }^{1}$, Jeong Ho Kim ${ }^{2}$, Seon-Hye Son ${ }^{1}$, Sang Gyu Kim ${ }^{1}$ and Young Ho Kim ${ }^{1 *}$ \\ ${ }^{1}$ Department of Agricultural Biotechnology, Seoul National University, Seoul 151-921, Korea \\ ${ }^{2}$ Korea Turfgrass Institute, Subsidiary of Korea Golf Course Business Association, Sungnam 463-840, Korea \\ (Received on June 7, 2008; Accepted on August 14, 2008)
}

\begin{abstract}
During routine surveys for pest and pathogen incidences at a golf course in 2007, circular to irregular patches of stunted, chlorotic and wilted turfgrass var. Pencross were noticed in Jinhae, Gyeongnam province, Korea. Soil samples collected from those diseased patches of the golf course yielded high population (average 126 nematodes/ $100 \mathrm{~cm}^{3}$ ) of a stunt nematode, Tylenchorhynchus claytoni, which is described and illustrated in this paper with light and scanning electron micrographs. This is the first report on the occurrence of $T$. claytoni in turfgrass in Korea.
\end{abstract}

Keywords : description, golf course, Korea, symptomatology, turfgrass, Tylenchorhynchus claytoni

Plant parasitic nematodes feed on all species of turfgrasses throughout the world and may be limiting factors in the production of high quality turf. Although their importance as a limiting factor in turfgrass production is not well defined, a high population level of many species of plant parasitic nematodes can cause severe damage to turfgrasses (Dunn and Nolling 1997; Tode and Tesserat, 1990). Several plant parasitic nematodes are reported to be associated with turfgrasses in Korea (Choo et al., 1998; Kang et al., 2003).

Stunt nematodes the genus Tylenchorhynchus (Nematoda, Tylenchida, Telotylenchinae) consist of several species. They are ectoparasites of roots, polyphagous in nature, and commonly found in vegetable fields, grasslands and forest soils. The species of stunt nematode have been reported to be associated with roots of turfgrasses in different parts of the world (Fushtey and McElroy, 1977; Sikora et al., 2001; Kang et al., 2003; Vargas, 2005). T. claytoni first identified by Steiner (1937) has been recorded from several crops in Korea (Choi, 2001) but on turfgrass it is reported here for the first time in Korea.

Nematode occurrence and symptoms. During routine disease surveys in Korea in 2007, patches of unhealthy turfgrass in a golf course in Jinhae, Gyeongnam province

\footnotetext{
*Corresponding author.

Phone) +82-2-880-4675, FAX) +82-2-873-2317

E-mail)yhokim@snu.ac.kr
}

were noticed. The symptoms observed were chlorosis and dieback of grass blades, reduced vigor, stunting and thinning of the turf in patches (Fig. 1). Symptoms appeared in circular to irregular areas, which is a typical characteristic of nematode infection because of their clustered distribution. T. claytoni was found in all soil samples collected from patches of diseased turfgrass var. Pencross with an average population density of 126 nematodes $/ 100 \mathrm{~cm}^{3}$ soil. No other pathogens causing similar patchy symptoms such as Rhizoctonia solani, Pythium spp. and Sclerotinia homeocarpa causing brown patch, pythium blight and dollar spot, respectively, were found from the patches. Tylenchorhynchus spp. are ectoparasites or sometimes semiendoparasites depending on host plants or soil environments. Their population densities required for plant damages would be much higher than endoparasitic nematodes such as rootknot nematodes Meloidogyne and root-lesion nematodes Pratylenchus. However, the high population of this nematode associated with poor areas in turfgrass suggests that $T$. claytoni may have caused severe damage to turfgrass in this golf course because the turfgrass is a perennial plant grown in a place that has been continuously exposed to nematode damages. Severe turfgrass damages also occur by similar ectoparasitic nematodes Belonolaimus spp. (Smiley et al., 1992). All of these aspects strongly suggest that the turfgrass disease be caused by T. claytoni.

Besides causing direct damage, Tylenchorhynchus species have also been known to increase the severity of fungal diseases on berseem (Trifolium alexandrinum) (Hasan and Bhaskar, 2004). Soil fungi, such as species of Fusarium, Rhizoctonia, and Pythium are common pathogens of turfgrasses and are likely to form disease complex. Therefore, further research is needed to determine the significance of this nematode on turfgrass and its possible interaction with other soil pathogens, so that proper control strategies can be recommended.

Nematode isolation and identification. Soil samples collected from patches of the infested turfgrass from golf courses were put in plastic bags, sealed and brought to the laboratory for nematode extraction. Each soil sample consisting of 4-5 cores, was mixed thoroughly by shaking the 


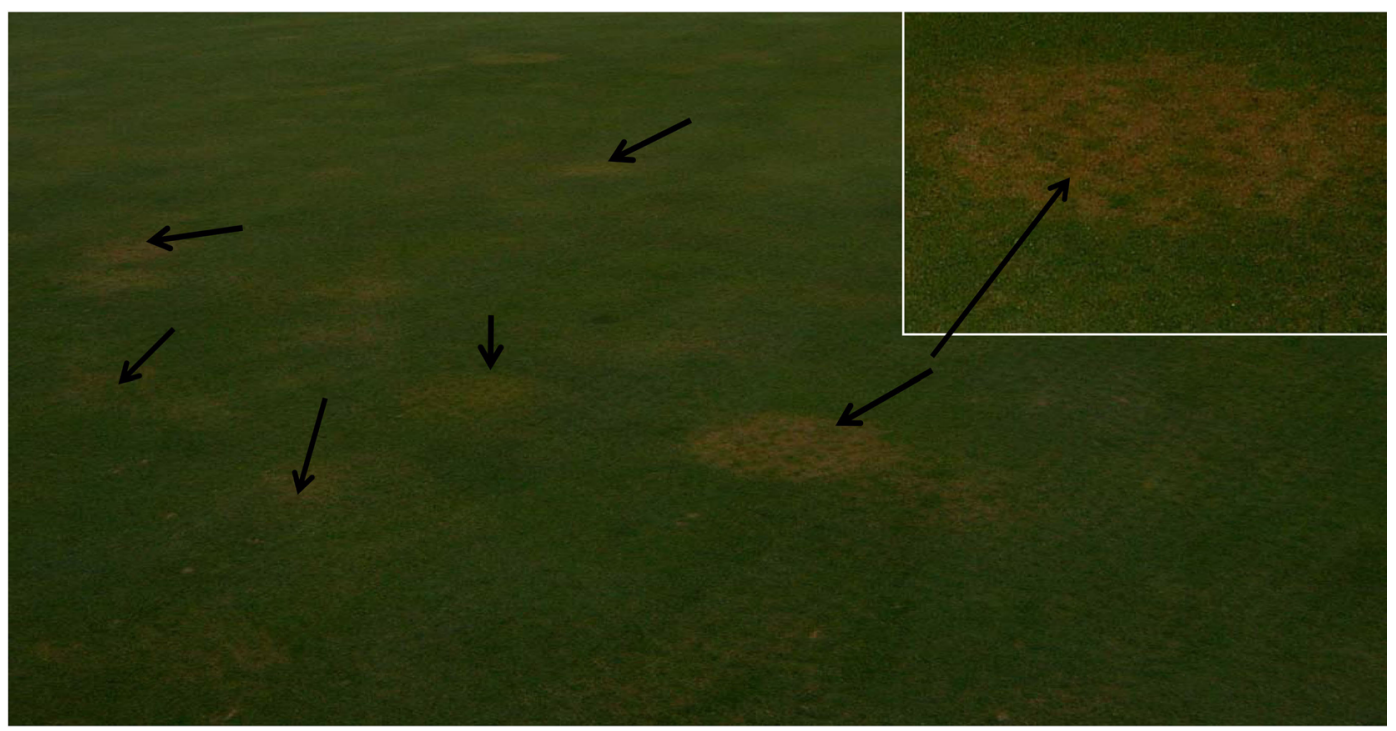

Fig. 1. Golf course showing symptoms of nematode infection on turfgrass, appeared in patches (arrows).

plastic bags, and nematodes were isolated from $300 \mathrm{~cm}^{3}$ soil sub-samples by sieving decantation and centrifugal flotation technique. Nematodes obtained in clear water were killed at $60^{\circ} \mathrm{C}$ and fixed in $4 \%$ formalin. Nematode populations were counted using a counting dish under a stereomicroscope. For taxonomic studies some specimens were processed for dehydration by Seinhorst's rapid glycerin method (1959) and mounted on glass slides in anhydrous glycerin. The nematodes obtained were observed under a compound light microscope (Axiophot, Zeiss,
Germany). For light microscope measurements, photographs were taken with digital photo camera (AxioCam HR, Zeiss, Germany) mounted on the microscope. DeMan's formula was used to determine pertinent values. For scanning electron microscopy (SEM), fixed specimens were treated with ultrasonic vibrator to remove any adhering detritus, dehydrated in graded ethanol series, critical point dried, sputter coated with gold, and observed under a scanning electron microscope (JSM-5410LV, Jeol, Tokyo, Japan).
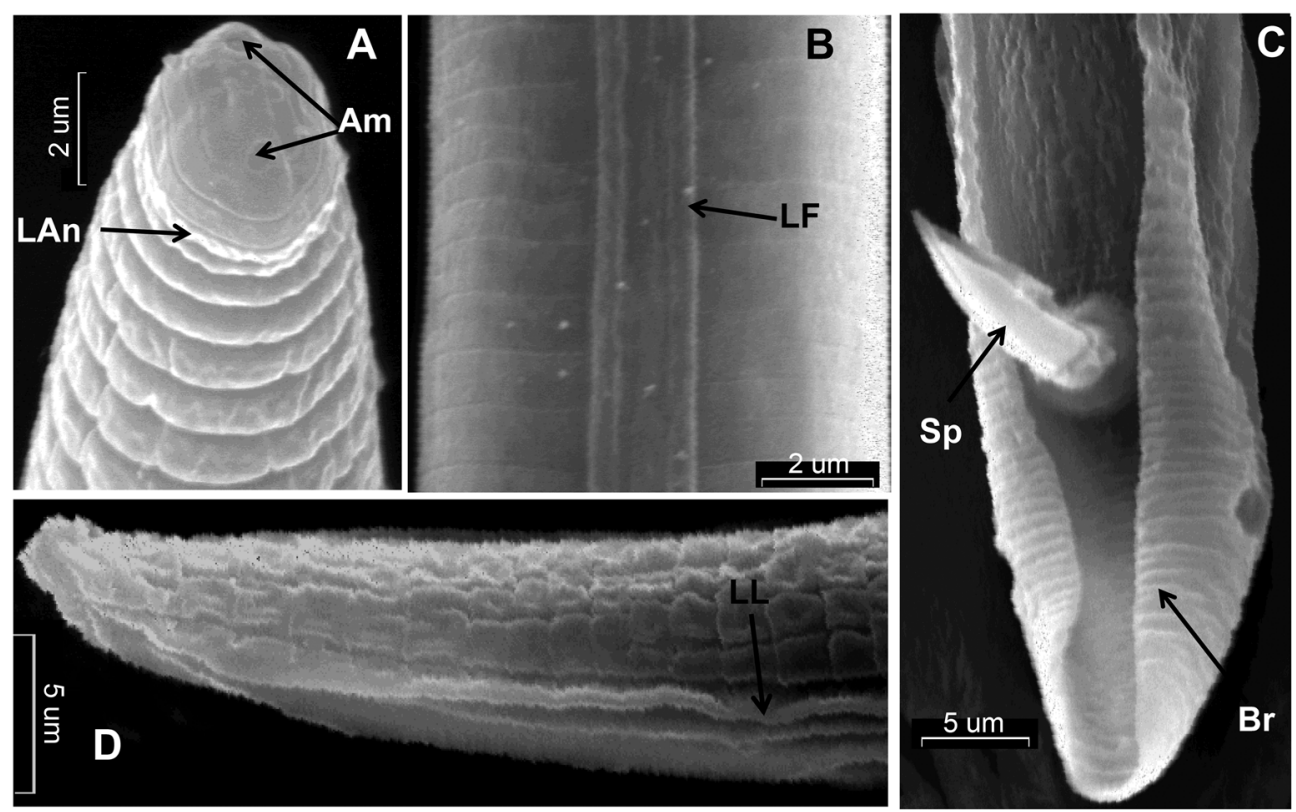

Fig. 2. Scanning electron micrographs of Tylenchorhynchus claytoni. (A) Anterior region, showing amphids (Am) and labial annules (LAn); (B) Lateral view of body, showing lateral field (LF); (C) Male posterior region, showing spicules (Sp) and bursa (Br); (D) Female posterior region, showing lateral line (LL) and tail shape. 

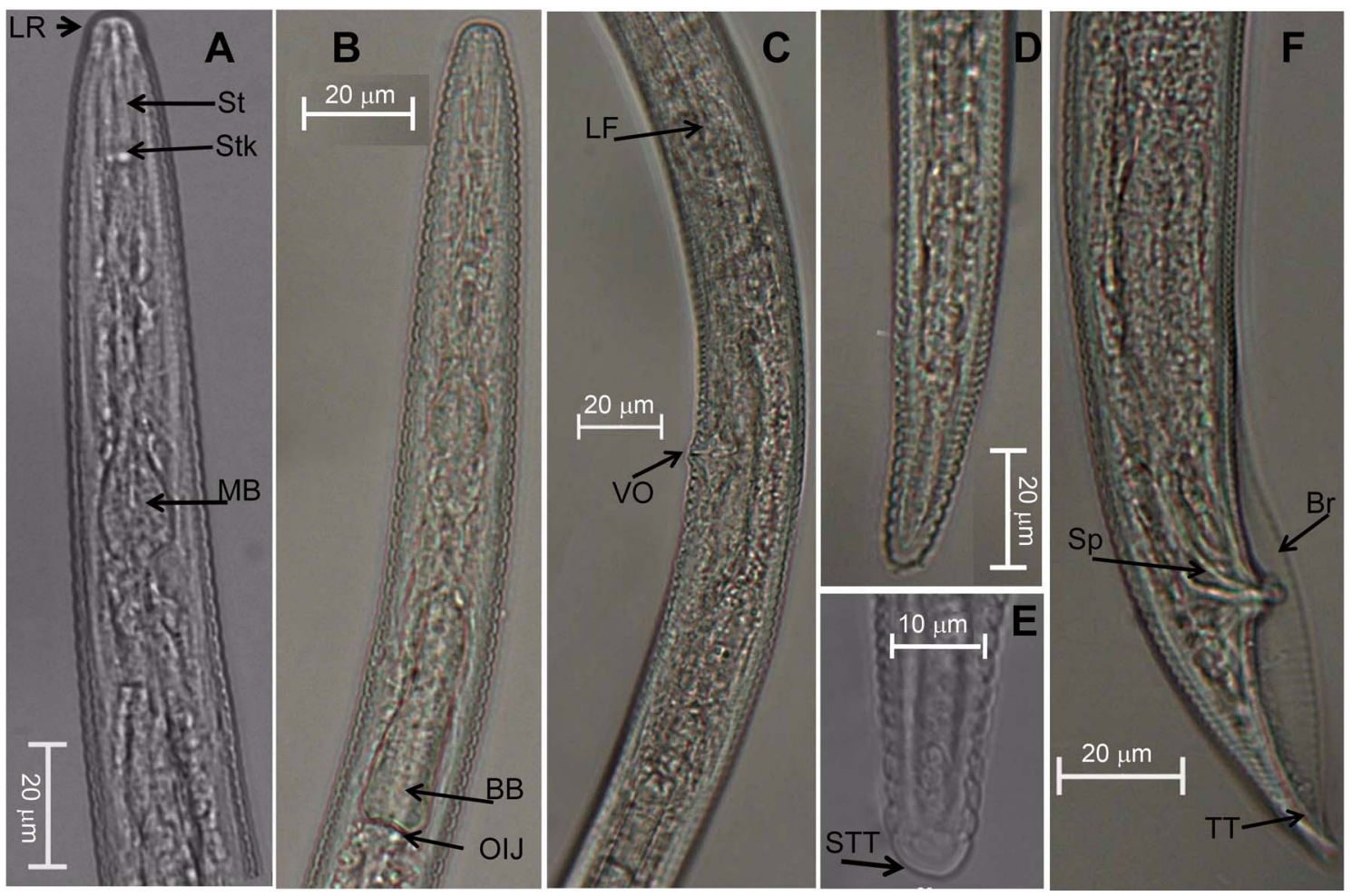

Fig. 3. Photomicrographs of Tylenchorhynchus claytoni. (A \& B) Anterior region, showing lip region (LR), stylet (St) and stylet knobs (Stk), median bulb (MB), basal bulb (BB) and oesophagointestinal junction (OIJ); (C) Middle part of body, showing lateral field (LF) and vulval opening (VO); (D \& E) Female posterior region, showing tail shape and smooth tail terminus (STT); (F) Male posterior region, showing spicules $(\mathrm{Sp})$, bursa $(\mathrm{Br})$ and tail terminus $(\mathrm{TT})$.

\section{Measurements}

Female ( $\mathrm{n}=10): \mathrm{L}=605-655 \mu \mathrm{m} ; \mathrm{a}=25.3-28.5 ; \mathrm{b}=4.6-5.2 ; \mathrm{c}$ $=14.7-17.2 ; \mathrm{c}^{\prime}=2.1-2.5 ; \mathrm{V}=55.5-57.4 \%$; stylet $=18-21 \mu \mathrm{m}$; tail $=38-43 \mu \mathrm{m} ; \mathrm{ABD}=17-21 \mu \mathrm{m}$.

Male (n=8): $L=590-636 \mu \mathrm{m} ; \mathrm{a}=29.7-31.7 ; \mathrm{b}=4.6-4.0 ; \mathrm{c}=$ 14.7-16.5; $\mathrm{c}^{\prime}=2.0-2.4 ; \mathrm{T}=54-60 \% ;$ stylet $=17.0-19.5 \mu \mathrm{m}$; tail $=37-42 \mu \mathrm{m} ; \mathrm{ABD}=16-21 \mu \mathrm{m}$; spicules $=23.0-26.5 \mu \mathrm{m}$.

\section{Description}

Female. Body straight or slightly ventrally curved when relaxed by heat. Cuticle with coarse transverse striations, 1.5-2.0 $\mu \mathrm{m}$ wide at mid-body. Lip region rounded and marked off from the body by slight constriction, $6-8 \mu \mathrm{m}$ in diameter; bearing 4 annules (Fig. 2A). Lateral fields 1/3-1/4 as wide as body width, with four incisures delimiting 3 bands (Fig. 2B, D). Amphidial apertures small pore-like, located dorsosubventrally (Fig. 2A). Stylet, slender, 18-21 $\mu \mathrm{m}$ long with rounded basal knobs (Fig. 3A, B). Oesophagus tylenchoid type, median bulb spheroid with distinct valve plates, isthmus long and narrow, basal bulb pyriform, offset from intestine (Fig. 3B). Vulva a transverse slit, vagina less than half of corresponding body width deep
(Fig. 3C). Reproductive system didelphic, amphidelphic; ovaries outstretched with oocytes arranged in a single row. Rectum less than half of anal body width long. Tail 2.2-2.8 anal body width long, tapering regularly to large rounded with 13-16 annules (Fig. 3D), terminus smooth (Fig. 3E).

Males. Body similar to female in general shape and morphology. Testis single, outstretched, with spermatocytes in a row. Spicules strong, ventrally arcuate (Fig. 2C), 1.3-1.4 anal body width long, with offset capitulum. Gubernaculum well developed arcuate, 11-13 $\mu \mathrm{m}$ long. Tail elongate conoid, 2.0-2.5 anal body width long. Bursa tylenchoid, enveloping entire tail with transverse cuticular striae (Figs. 2C, 3F).

Remarks. The present population of T. claytoni is identified by using the diagnostic key to the species of the genus Tylenchorhynchus provided by Handoo (2000). The morphometric data and morphological characteristics of the present population match well with other Korean populations given by Choi (2001) as well as with its original description.

\section{Acknowledgement}

This study was carried out with the support of "Research 
Cooperating Program for Agricultural Science \& Technology Development (Project No. OA-20060501036009)", Rural Development Administration, Republic of Korea.

\section{References}

Choi, Y. E. 2001. Nematoda (Tylenchida, Aphelenchida). Economic Insects of Korea 20. Ins. Korean Supplement 27:392 pp.

Choo, H. Y., Lee, D. W., Kim, H. H., Park, J. W., Sung, Y. T. and Chung, Y. K. 1998. A newly recorded turfgrass pest, root-knot nematode, Meloidogyne incognita, in Korean golf courses. Korean Turfgrass Sci. 12:107-112.

Dunn, R. A. and Nolling, J. W. 1997. Foliar nematode management guide. Florida Cooperative Extension Service, SP-54. University of Florida, Gainesville, Fl, USA.

Fushtey, S. G. and McElroy, F. D. 1977. Plant parasitic nematodes in turfgrass in southern British Columbia. Invertebrate des Maladies des Plantes au Canada 57:54-56.

Handoo, Z. 2000. A key and diagnostic compendium to the species of the Genus Tylenchorhynchus Cobb, 1913 (Nematoda: Belonolaimidae). J. Nematol. 32:20-34.

Hasan, N. and Bhaskar, R. B. 2004. Disease complex of berseem involving nematode and two soil inhabiting fungi. Ann. Plant Prot. Sci. 12:159-161.

Kang, Y. J., Lee, D. W., Choo, H. Y., Kweon, T. W., Shin, J. C., Shin, H. K., Choi, I. G. and Choi, Y. E. 2003. Turfgrass nematodes isolated from some golf courses. Korean Turfgrass Sci. 17:81-85.

Seinhorst, J. W. 1959. A rapid method for the transfer of nematodes from fixative to anhydrous glycerin. Nematologica 44:67-69.

Sikora, E. J., Guertal, E. A. and Bowen, K. L. 2001. Plantparasitic nematodes associated with hybrid bermudagrass and creeping bentgrass putting green in Alabama. Nematropica 31:301-305.

Smiley, R. W., Dernoeden, P. H. and Clarke, B. B. 1992. Compendium of Turfgrass Diseases. APS Press. The American Phytopathological Society, MN, USA. 98 pp.

Steiner, G. 1937. Opuscula Miscellanea Nematologica v. Tylenchorhynchus claytoni, n.sp., an apparently rare nemic parasite of the tobacco plant. Proc. Helminthol. Soc. Washington 4:33-34.

Vargas, J. M. M. 2005. Management of Turfgrass Disease. John Wiley and Sons, New Jersey and Canada. 320 pp. 